\title{
ASTACOPSIS GOULDI CLARK IN STREAMS OF THE GOG RANGE, NORTHERN TASMANIA: THE EFFECTS OF CATCHMENT DISTURBANCE
}

\author{
by Ivor $\mathrm{O}$. Growns
}

(with one table and two text-figures)

Growns, 1.O., 1995 (30:vi): Astacopsis gouldi Clark in streams of the Gog Range, northern 'Tasmania: the effects of catchmene disturbance.

Pap. Proc. R. Soc. Tasm. 129: 1-6 https://doi.org/10.26749/rstpp.129.1 ISSN 0080-4703. AWT EnSight, 51 Hermitage Road, West Ryde, NSW, Australia 2114.

Populations of the giant freshwater crayfish, Astacopsis gouldi, were sampled in the Gog Range, northern Tasmania. 'Ten sites were sampled in relatively undisturbed and minimally disturbed areas, and in areas with a history of severe carchment disturbance. Larger numbers of A. gouldi were caught in two streams with relativcly undisturbed catchments than in three strcams in heavily disturbed catchnents. Thus, the abundance of $A$. gouldi in the Gog Range appears to have been adversely affected as a result of the disturbance of the original vegetation. Although the precise mechanism of the impact cannoc be determined from this study, sedimentation and the presence of culverts may be preventing recolonisation of the disturbed streams. This study indicates the potential for catchment disturbance to affect populations of A. gouldi and highlights the need for proper management of land uses that may be detrimental to this species.

Key Words: Astacopsis, catchment disturbance, Tasmania

\section{INTRODUCTION}

The giant freshwater crayfish, Astacopsis gouldi Clark 1936, is the world's largest freshwater crayfish and is endemic to northern parts of Tasmania. It is widely distributed in streams, rivers and reservoirs draining to Bass Strait, as well as in the Arthur River system in far northwestern Tasmania (Swain et al. 1982).

The status of $A$. gould $i$ has been described as "vulnerable" by the International Union for the Conservation of Nature in its Invertebrate Red Data Book (Wells et al. 1983), "indeterminately threatened" by Horwitz (1990) and "threatened" by Horwitz (1994). The main processes that have been identified as having the potential to disrupt populations of this species include fishing pressure and destruction of habitat e.g. through land clearing (Lynch 1969, Horwitz \& Hamr 1988, Hamr 1990).

There is little information about the habitat requirements of $A$. gouldi and how changes in land use affect populations. Changing the land use in a formerly pristine catchment, such as clearing land for agricultural or forestry purposes or the removal of riparian vegetation, is likely to severely disrupt crayfish habitat. This could happen in several ways. Increased light and temperature levels, modification of habitat structure and a decrease or change in the input of woody material can all result from the removal of riparian vegetation (Graynoth 1979, Haefner \& Wallace 1981, Silsbee \& Larson 1983, Campbell \& Doeg 1989). These factors can reduce water quality and the number of refuges and amount of food available to the crayfish. Conversion of native riparian vegetation to alien species, such as willows and pines, may also reduce available food or refuges. An intact riparian vegetation strip left along the stream edge can ameliorate not only these effects but those of other anthropogenic disturbances, such as increases in sedimentation and pesticides, by acting as a buffer between the land use and the stream system. Intact riparian vegetation also maintains stream integrity and morphology (Erman et al. 1977, Newbold et al. 1980, Culp \& Davies 1983).

The aim of this study was to assess the impacts of alteration of catchment vegetation on $A$. gouldi populations in the
Gog Range, northern Tasmania. This was achieved by comparing the abundance and population structure in streams running through catchments with different histories of catchment disturbance, including old Pinus radiata plantations (with regeneration of native riparian components), recently cleared land (with an intact riparian zone), and relatively undisturbed catchments with native vegetation. Some of the sites were subject to fishing pressure, as indicated by the presence of bait lines.

\section{STUDY SITES}

A total of ten sampling sites was established on Garden of Eden Creek, Eel Hole Creek and tributaries of the Minnow River draining the northern face of the Gog Range in northern Tasmania (fig. 1, table 1). The streams are second or third order, approximately $1 \mathrm{~m}$ wide, within $8 \mathrm{~km}$ of each other and geomorphologically homogeneous.

The catchments of Garden of Eden and Eel Hole Creeks are dominated by natural vegetation. There is a small portion near the headwaters of Garden of Eden Creek which now supports young pine (Pinus radiata) plantations, and some agricultural land near where Garden of Eden Creek runs into the Mersey River. Also, a small section of Garden of Eden Creek catchment was clearfelled in the spring and summer of 1992.

The catchment of Garden of Eden Creek has a Eucalyptus delegatensis and E. viminalis canopy with an understorey of -learia argophylla, Acacia melanoxylon, Coprosma quadrifida and Dicksonia antarctica. The dominant ground-cover plants are Pteridium esculentum (bracken fern), Rubus fruticosus (blackberry), and Blechnum nudum. The substratum of the sampling sites in Garden of Eden Creek appeared to be slightly silted, possibly due to the clearfelling within its headwaters.

Eel Hole Creek catchment is dominated by rainforest species including Nothofagus cunninghamii, Atherosperma moschatum, Acacia melanoxylon and Pomaderris apetala. The understorey comprises Olearia argophylla, Coprosma quadrifida, Dicksonia antarctica and Gahnia grandis. 


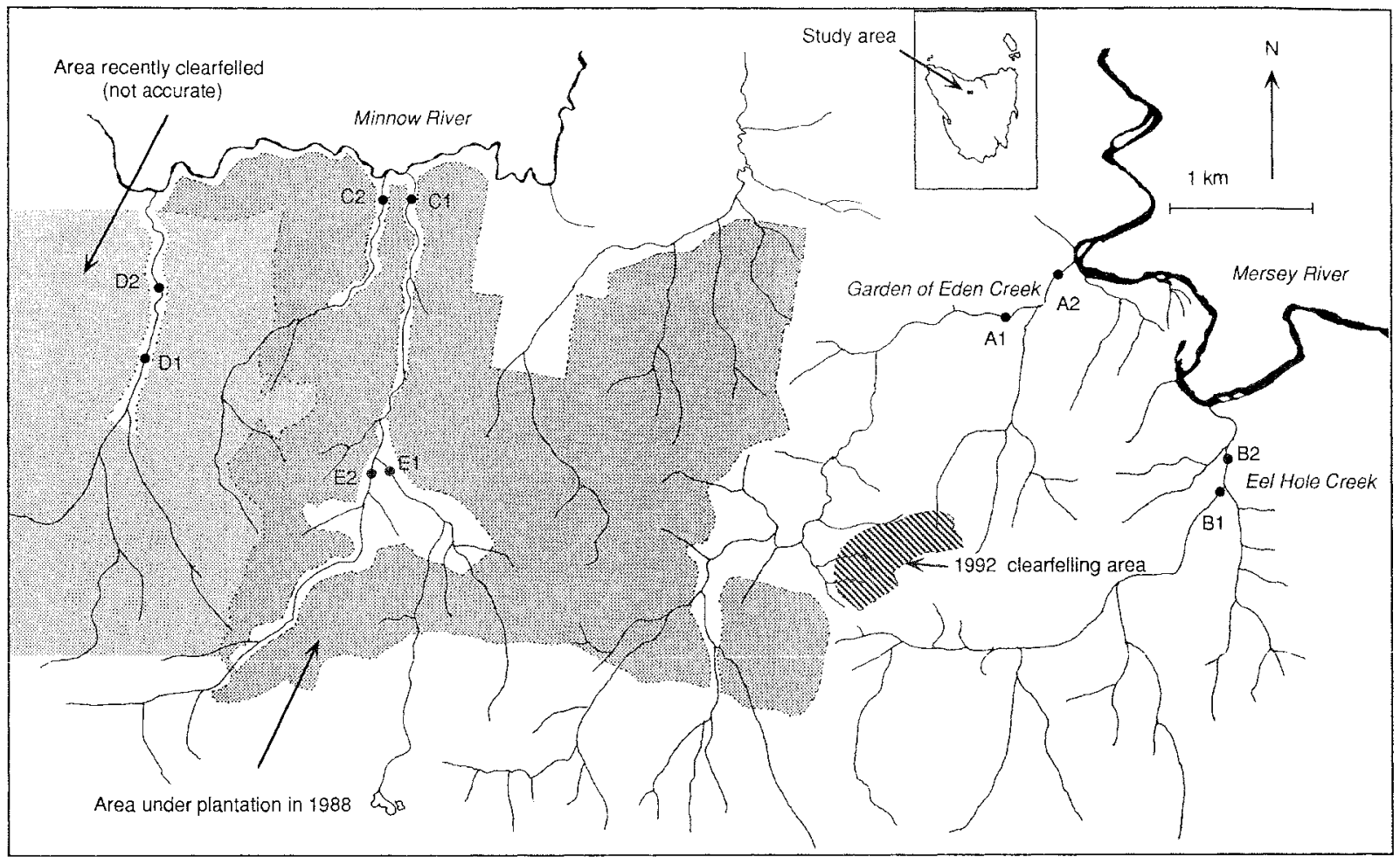

FIG. 1 - Site locations within the Gog Range.

TABLE 1

Characteristics of sampling sites

\begin{tabular}{|c|c|c|c|c|}
\hline Site & $\begin{array}{l}\text { Altitude } \\
(\mathrm{m})\end{array}$ & $\begin{array}{c}\text { Canopy } \\
\text { cover } \\
(\%)\end{array}$ & $\begin{array}{c}\text { Width of riparian } \\
\text { zone present during } \\
\text { land clearing within } \\
\text { catchment }\end{array}$ & Catchment history \\
\hline A1 & 100 & 50 & None in headwaters & Headwaters cleared, selectively logged forty years ago \\
\hline $\mathrm{A} 2$ & 100 & 5 & $\begin{array}{l}\text { None in headwaters } \\
\text { or in agricultural } \\
\text { section }\end{array}$ & $\begin{array}{l}\text { Headwaters cleared, selectively logged forty years ago } \\
\text { and area nearby converted to pasture }\end{array}$ \\
\hline B1 & 120 & 70 & - & Natural vegetation \\
\hline B2 & 100 & 70 & - & Natural vegetation \\
\hline $\mathrm{C} 1$ & 200 & $<15$ & 40 m wide $^{*}$ & Clearfelled, no regeneration \\
\hline $\mathrm{C} 2$ & 200 & 35 & $40 \mathrm{~m}$ wide & Clearfelled, ten year old pine plantation \\
\hline D1 & 220 & 20 & $40 \mathrm{~m}$ wide & Recently clearfelled, no regeneration \\
\hline D2 & 240 & 20 & $40 \mathrm{~m}$ wide & Recently clearfelled, no regeneration \\
\hline E1 & 250 & 35 & $0 \mathrm{~m}$ & $\begin{array}{l}\text { Heavy selective logging } 15-17 \text { years ago, natural regeneration but } \\
\text { old pine plantation nearby }\end{array}$ \\
\hline E2 & 250 & 60 & $0 \mathrm{~m}$ & $\begin{array}{l}\text { Heavy selective logging } 15-17 \text { years ago, natural regeneration but } \\
\text { old pine plantation nearby }\end{array}$ \\
\hline
\end{tabular}

\footnotetext{
* But damage exists resulting from passage of a skidder through the stream in several places.
} 
Two sampling sites were established on each of these streams, $A 1$ and $A 2$ (on Garden of Eden Creek) and B1 and B2 (on Eel Hole Creek). Sites A1, B1 and B2 were surrounded by natural vegetation, while site $\mathrm{A} 2$ was located within the agricultural land section. Pasture up to the waters edge allowed easy access to the water at this site.

The remaining six sampling sites $(\mathrm{C} 1, \mathrm{C} 2, \mathrm{D} 1, \mathrm{D} 2, \mathrm{E} 1$ and E2) were established on three tributaries of the Minnow River (fig. 1). The vegetation surrounding these sampling sites varied from natural regeneration after heavy selective logging (surrounded by old pine plantation), with no streamside reserve, to recently clearfelled with no regeneration but with a $40 \mathrm{~m}$ streamside reserve required under the Tasmanian Forest Practices Code (table 1). The dominant remaining native vegetation within the catchments of these streams is similar to that of Garden of Eden Creek, although the understorey in the heavy selectively logged area had a dense understorey of Pomaderris apetala. A native Blackwood (Acacia melanoxylon) plantation was planted within the catchment of site $\mathrm{Cl}$, but no regeneration had taken place by the time of the presen study. Sedimentation at these sites (as indicated by casual observation) ranged from negligible at sites C2, E1 and E2, with some evident in D1 and D2, to heavy sedimentation of parts of $\mathrm{C} 2$.

The clearfelling that took place at sites E1 and E2, where no streamside reserve was left intact, was undertaken on private land. This land has since been purchased by the Forestry Commission.

\section{METHODS}

Sampling was carried out during the summer of 1993, from 9 January to 13 March. Each site was sampled nine times during this nine-week period. At each of the ten sites, 150 $\mathrm{m}$ of stream was marked with surveyors tape. Between 10 and 15 fresh mutton baits were laid along the same length of the stream each day. All baited lines were inspected periodically throughout the 6-8 hr sampling period each day. If a bait remained untouched for several hours, it was usually moved to a new location within the sampling area. In addition to baiting, crayfish were also collected by hand by overturning logs and rocks wherever possible. A team of two people usually sampled two sites on each day. Thus, the effort used to catch crayfish was the same, wherever possible, at each site over the entire sampling period.

Because of the likelihood of encountering more than one species of Astacopsis in the streams of the Gog Range, each animal caught was identified according to Hamr (1992). Animals were marked with an unique identifying tail puncture and a number scratched on the top of the carapace. The carapace length (cpl), the length from the rostrum tip to the back of the carapace, and the sex of every individual caught were recorded. Large females were examined for the presence of eggs or young. Animals with soft carapaces were also noted, as this is an indication of the animals having either just moulted or being about to.

As an indication of recreational fishing pressure at each site, the presence of bait lines was noted. The lines were then removed, so that new bait lines could be identified during the sampling period.

\section{RESULTS}

A total of 131 individual $A$. gouldiwere caught, ranging from 10.0 to $177.8 \mathrm{~mm} \mathrm{cpl}$, in approximately 630 fishing hours (fig. 2). Five A. tricorniswere also collected from sites B 1, B2, E1 and E2, ranging from 27.0 to $47.2 \mathrm{~mm} \mathrm{cpl}$.

The greatest number of crayfish were caught at sites B 1 and B2 (40 and 42 individuals respectively) in the undisturbed catchment on Eel Holc Creek (fig. 2). Approximately half as many crayfish were caught at sites $A 1$ and $A 2$ on the Garden of Eden Creek. A total of seven A. gouldi were caught at the six sites on the tributaries of the Minnow River, with highly disturbed catchments.

Of the 131 crayfish caught, only 11 were of legal size (i.e. $>130 \mathrm{~mm}$ carapace length). Most animals caught were less than $80 \mathrm{~mm} \mathrm{cpl}$, and these were caught at sites A1, A2, B1 and B2 (fig. 2). The size distribution of crayfish with carapace lengths greater than $80 \mathrm{~mm}$ is evenly spread at all sites. Most of the crayfish from the disturbed sites were large males (greater than $100 \mathrm{~mm} \mathrm{cpl}$ ). Of all the crayfish marked, only $16(12 \%)$ were recaptured at least once.

Three female crayfish carrying young were caught, two individuals at site Al $(137.0$ and $129.0 \mathrm{~mm} \mathrm{cpl})$ and one individual at site $\mathrm{B} 2(122.7 \mathrm{~mm} \mathrm{cpl})$.

Three crayfish were observed moving between sites on Eel Hole Creek (sites B1 and B2). Two males (101.0 and $87.5 \mathrm{~mm} \mathrm{cpl}$ ) were caught and marked at site B1 and subsequently recovered from site B2. A berried female (122.7 mm cpl), originally marked at site B2, was recaptured at site $\mathrm{B} 1$. This indicates that individuals of this species are motile and that marked animals are capable of moving out of the study areas.

Bait lines were observed at all sites except $\mathrm{C} 1$ and $\mathrm{C} 2$. The only site with old and new bait lines was A2, possibly indicating ongoing fishing pressure at this site.

\section{DISCUSSION}

This study has shown that $A$. gouldipopulations are virtually non-existent in streams of catchments that have been heavily, disturbed by clearfelling within the Gog Range. Also, the catches of this species at sites in the undisturbed catchment (Eel Hole Creek) were double that in the stream with the majority of its catchment covered by native vegetation but with some catchment disturbance (Garden of Eden Creek). These results are supported by other literature, which indicates that habitat degradation or destruction can be detrimental to populations of freshwater crayfish in Australia and the Northern Hemisphere (Westman 1985, Geddes 1991, Merrick 1993, Horwitz 1994).

This study to establish the effects of catchment disturbance on populations of $A$. gouldi could be criticised on the grounds that there is no information available on the abundances of this species before the disturbance took place; the streams may have supported different densities of $A$. gouldi before European settlement. There is no obvious reason why the populations within each of the streams should have been different before then. All the streams are of a similar altitude, width and geological type, and would have similar rainfall and discharge patterns. However, the possibility cannot be ruled out that there may have been other factors, not measured in this study, that were different between the streams and could have affected the abundances of A. gouldi. 

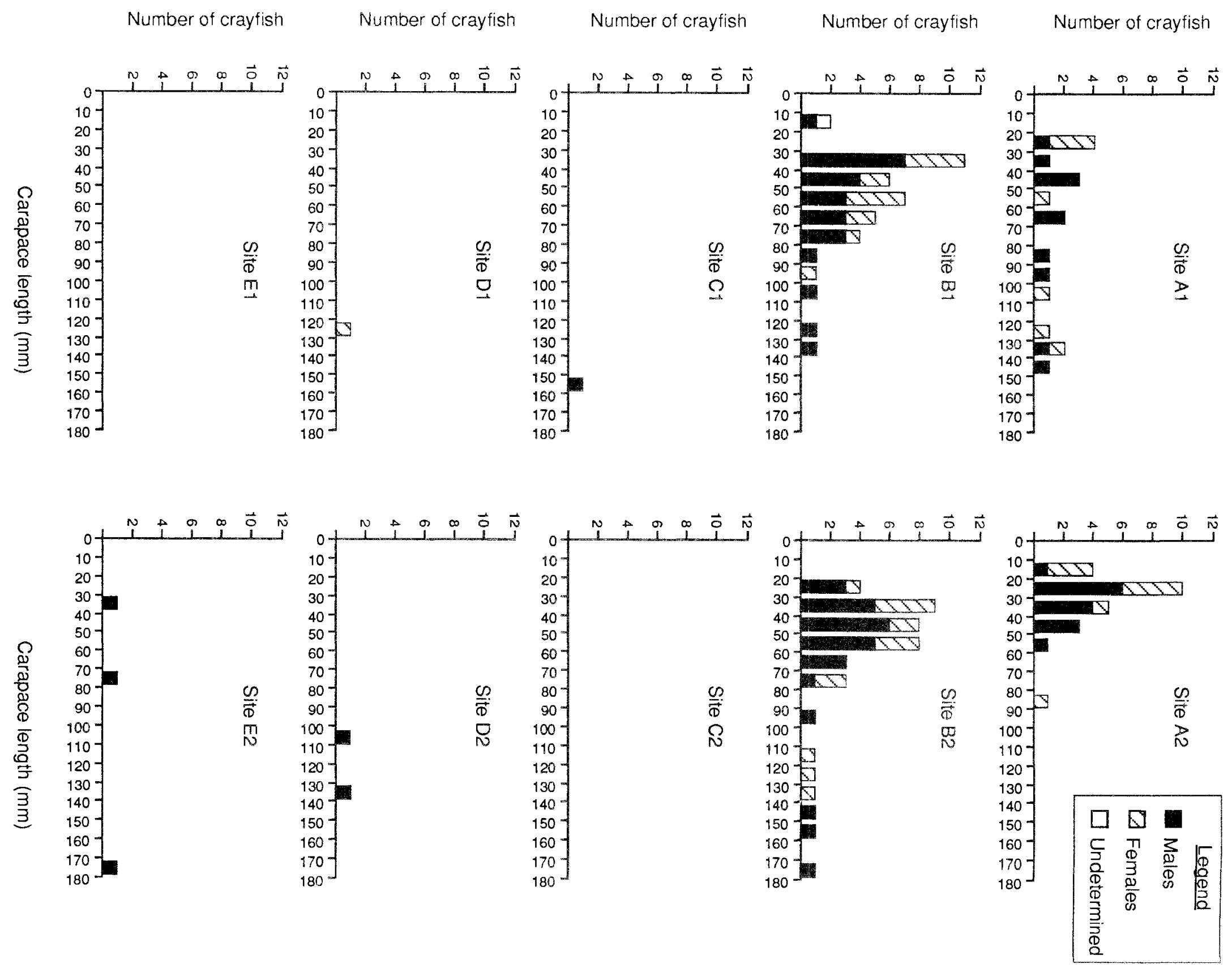
A much larger population of $A$. gouldi was expected in the streams in the heavily disturbed catchments, because the stream morphology at most sites appeared similar to that of streams with mostly intact native vegetation. One would have expected, therefore, recolonisation of these habitats after any initial adverse effects of clearfelling. There are several reasons why recolonisation may not have taken place within these streams.

Firstly, the present habitat in the tributaries of the Minnow River used in this study may be unsuitable for recolonisation. It is unlikely that the present habitats are totally unsuitable for crayfish, because some large crayfish and small Astacopsis already exist there and, as noted earlier, all the streams generally resemble each other. However, the amount of sediment observed at some sites may be limiting habitat availability in some manner.

Secondly, individual crayfish may be relatively sessile, have small home ranges and not readily migrate to new areas. It is unknown how motile $A$. gouldi individuals are, but crayfish in the present study were recorded moving between sites on the same stream. Also, only a small percentage of animals that were marked over $100 \mathrm{~m}$ of stream at each site were recaptured, indicating thar they may have moved outside the study areas. These findings suggest that this species is relatively motile and, therefore, it is likely that disturbed areas would be recolonised, if opportunities arose to do so.

Thirdly, there may be no nearby breeding populations to provide recruitment. A large proportion of the catchment of the Minnow River has been cleared for agricultural purposes, and crayfish populations are subject to strong fishing pressure (J. Dudley \& J. Nelson, pers. comm.). Habitat degradation and fishing pressure within the rest of the Minnow River catchment may limit the numbers of animals that are able to recolonise areas denuded of crayfish. However, the Minnow River is known locally as a good "lobster" creek (J. Nelson, pers. comm), indicating that it may support a substantial population of crayfish.

Finally, recolonisation may be prevented, due to limited available crayfish passage from recruiting areas. Each of the sites that were sampled on the tributaries of the Minnow River are separated from the Minnow River by between one and four culverts (round pipes laid under roads to allow passage of water). There is increasing evidence that crayfish are not able to negotiate passage through culverts, because of the higher velocity of water that travels through them and the smooth sides that do not allow the crayfish to obtain a grip (Horwitz 1991). However, there is anecdotal evidence which suggests that crayfish can move over land to reach streams. This behaviour is common in the mainland crayfish genus Euastacus (Morgan 1983), but it is not known how common it is in $A$. gouldi.

The influence of fishing pressure on $A$. gouldipopulations in the Gog range cannot be judged from the data produced during this study. Sampling of contrasting populations with and without fishing pressure was only available at sites with highly disturbed catchments and low numbers of crayfish; the small number of animals at these sites would limit the detection of differences between these populations. The sites with relatively undisturbed catchments all had some indication of fishing pressure. However, without knowing the extent of the fishing pressure and the number or size of animals removed by recreational fishers at these sites, it is difficult to determine any effect of fishing.
This study has been a small-scale survey on various factors affecting populations of $A$. gouldi, and the conclusions that can be drawn from it are limited by the nature of the sampling design and the lack of the general knowledge of the biology, ecology and behaviour of $A$. gouldi. To identify the mechanisms of how changes in land use affect crayfish populations, and orher issues, such as barriers to recolonisation, further research is needed, so that effective management can be put in place. This study indicates the potential for land clearing to affect populations of $A$. gouldi and highlights the need for proper management of land uses that maybe detrimental to this species.

\section{ACKNOWLEDGMENTS}

Primary thanks go to the members of the Deloraine Field Naturalists Club Inc. who precipitated and participated in this study. These people are too numerous to name individually, but John Dudley, Andrew Hingston, Jim Nelson, John Petraitis, Paul Swiatkowski, Micah Visoiu and Bruce Worth are especially thanked. Jim and Claudia Nelson and John and Corrie Dudley provided accommodation for the author during the sampling programme.

People who read and commented on earlier drafts of the manuscript include Kim Felton, Jane Growns, Premek Hamr, Pierre Horwitz, Paul Humphries, Martin Krogh, Sam Lake, John Merrick, Jim Nelson, Dave Pollard, Alastair Richardson, Rob Taylor and Tim Wardlow.

The project was funded by the Endangered Species Program of the Australian Nature Conservation Agency (ANCA ESP project no. 214) and the Tasmanian Conservation Trust is thanked for administering the grant. The Zoology Department of the University of Tasmania is thanked for the provision of its facilites and Dr Alastair Richardson for the use of his equipment. The Tasmanian Forestry Commission is thanked for withholding any logging activity within the catchment of Eel Hole Creek until the fieldwork for this study had been completed. The Inland Fisheries Commission of Tasmania is thanked for the permission to sample populations of $A$. gouldi within the Gog Range.

\section{REFERENCES}

CAMpBeil, I.C. \& Dofg, T.J., 1989: Impact of timber harvesting and production on streams: a review. Aust. J. Mar. Freshw. Res. 40: 519-539

CLARK, E., 1936: The freshwater and land crayfishes of Australia. Mem. Natl Mus. Vic. 10: 5-58.

CUI.P, J.M. \& DAVIES, R.W., 1983: An assessment of streambank clearcutting on macroinvertebrate communities in a managed watershed. Can. Tech. Rep. Fish. Aquat. Sci. 1208.

Erman, D.C., Newboin, J.D. \& Roby, K.B., 1977: Evaluation of streamside buffer strips for protecting aquatic organisms. California Water Resour. Cent. Tech. Completion Rep. 165.

Geddes, M.C., 1991: The crayfish. In Mackay, N. \& Eastburn, D. (Eds): THE MURRAY. CSIRO, Melbourne: 303308

GrayNOTH, E., 1979: Effects of logging on stream environments and faunas in Nelson. NZ J. Mar. Freshw. Res. 13: 79109. 
Haefner, J.D. \& Wallace, J.B., 1981: Production and potential seston utilisation by Parapsyche cardis and Diplectrona modesta Trichoptera: Hydropsychidae in two streams draining contrasting southern Appalachian watersheds. Environ. Entomol. 10: 433-441.

HAMr, P., 1990: Rare and endangered: Tasmanian giant freshwater lobster. Aust. Nat. Hist. 23: 362.

Hamr, P., 1992: A revision of the Tasmanian freshwater crayfish genus Astacopsis Huxley (Decapoda: Parastacidae). Pap. Proc. R. Soc. Tasm. 126: 91-94.

HonwIY\%, P.H.J., 1990: Conservation status of Australian freshwater crustacea. Aust. Natl Parks Wildl. Serv. Rep. Ser. 14.

Horwitz, P.H.J., 1991: On the distribution and exploitation of the Tasmanian giant freshwater lobster Astacopsis gouldi Clark. Report to the Office of the National Estate, Tasmania.

Hokwmz, P.H.J., 1994: Distribution and conservation status of the Tasmanian giant freshwater lobster Astacopsis gouldi (Decapoda: Parastacidae). Biol. Conserv. 69: 199-206.

Horwitz, P.H.J. \& Hamr, P., 1988: An assessment of the Caroline Creek Freshwater Crayfish Reserve in northern Tasmania. Pap. Proc. R. Soc. Tasm. 122: 69-72.

LYNCH, D.D., 1969: The giant freshwater crayfish of Tasmania, Astacopsis gouldi. Bull. Aust. Soc. Limnol. 2: 20-21.

MERRICK, J.R., 1993: FRESHWATER CRAYFISHES OF NEW SOUTH WALES. Linnean Society of NSW, Sydney.
Morgan, G.J., 1983: Taxonomic revision of freshwater crayfish of the genus Euastacus Clark Decapoda: Parastacidae. Unpubl. PhD thesis, Monash Univ.

Newbolo, J.D. Erman, D.C. \& Roby, K.B., 1980: Effects of logging on macroinvertebrates in streams with and without buffer strips. Can. J. Fish. Aquat. Sci. 27: 10761085.

Silsbee, D.G. \& Larson, G.L., 1983: A comparison of streams in logged and unlogged areas of Great Smoky National Park. Hydrobiologia 102: 99-111.

SWAN, R, Richardson, A.M.M. \& Hortrli, M., 1982: Revision of the Tasmanian genus of freshwater crayfish Astacopsis Huxley Decapoda: Parastacidae. Aust. J. Mar. Freshw. Res. 33: 699-709.

Whil.s, S.M., Pylf, R.M. \& Collins, N.M., 1983: THE INTERNATIONAL UNION FOR THE CONSERVATION OF NATURE INVERTEBRATE RED DATA $B O O K$. IUCN, Gland, Switzerland.

WESTMAN, K., 1985: Effects of habitat modification on freshwater crayfish. In Alabaster, J.S. (Ed.): HABITAT MODIFICATION AND FRESHWATER FISHERIES. FAO Publication, Butterworths, London.

(accepted 15 June 1994) 